\title{
The Development of Islamic Religion Education Curriculum at University Seen From the Perspective of Maqashid
}

\author{
Ahmad Arifi ${ }^{1 *}$

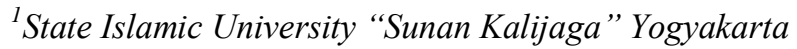 \\ *Corresponding author E-mail: arifi.ty66@gmail.com
}

\begin{abstract}
In this present globalization era, many fields of changes occur, especially in education field which runs rapidly and dynamically. An individual's science, technology, and competence will quickly obsolete it they are not upgraded. Thus, it is required education curriculum development, especially Islamic Religion Education so that they are able to answer era challenge. This study is aimed to explain the development of Islamic Religion Education (IRE) curriculum development at universities seen from the perspective of Maqashid. In this context, curriculum development which is based on maqashid is a curriculum development based on maqashid is a curriculum development which is based on contextual objective which adapt dynamic era development that is a curriculum which is able to cover various recent developments and objective which direct learners to the natural benefit (rahmatan lil alamin). Research method which is utilized is natural qualitative. This research has been successful to collaborate philosophical base of curriculum development of Islamic Religion Education Study Program seen from maqashid perspective. This research concludes that the development of curriculum of Islamic Religion Education at Tarbiyah and Teachers Training Science Faculty, UIN Sunan Kalijaga orients on values of rahmatan lil 'alamin manifested in three things: First, the study program vision has possessed value philosophy which supports the achieved civil society through interconnection integration of science in the context of developing world peace and civilization. Second, preparing learners to be able to fulfill national qualification standard by developing curriculum which refer on Indonesian Qualification Framework (IQF) and High Education National Standard (SNPT) and fulfill University International Qualification, which is ASEAN University Network-Quality Assurance (AUN-QA). Third, preparing learners to have open attitude, live in harmony in the multicultural society and able to behave cooperatively in maintaining morality values.
\end{abstract}

Keywords: Curriculum Development; Islamic Religion Education; Maqashid

\section{Introduction}

The future challenge of Indonesia nation in education world in 2020 is World Trade Organization (WTO) and at present has entered Asean Economic Society (AES) era. The consequence of world single market in education field is University graduates who are able to compete in the International World. The implication is that education (university) is important and demanding to prepare its graduates to have competitive independence and preparation. The preparation of competitive graduates can only be prepared by education institutions to achieve expected graduates profiles and written in the University Education Curriculum, the profile of graduates become the attractiveness and acceptability cohesiveness power of the graduates in the work field.

In order to prepare it the development of curriculum becomes important because curriculum is understood specifically and generally. Specifically, curriculum is lesson or course taught to students. While generally curriculum is defined as learning experience bot at school or campus. All attach on university institution which internally in form of written, taught and tested curriculum. Curriculum as the capital becomes the reference of university institution. The ability of University or college to know ,use and develop social capital as the success key of university implementation.

In the Higher Education Long Term Strategy (HELTS), National Education Ministry Year 2010, it has been explained that the man- agement of university/college is oriented on autonomy, healthy management, and efficiency. Also, the development of curriculum pays attention to internal and external factor and use science discipline role, and Indonesian nation aspiration. This aspiration can be introduced in the objective of Indonesian National Education covered in Act no.20 Year 2003 on national education system which can simply be formulated to make Indonesian nation good and smart. Thi objective is responded by the government through College Education National Standard Number 39 year 2014 which try to build soft skills and hard skills.

Therefore, through this education the future nation becomes a nation which has harmony between attitude and intelligence integrative (1). Integrated personality will shape when the interconnection-integrated based science development which does not differ between general and religious science which is sourced from AlQuran and Hadith. This aspiration is implemented and relied on college education curriculum development which refers on KKNI, SNPT (INQD,CENS) and science integration- interconnection. There are two important things proposed in achieving a nation that has integrated attitude and intelligence, which are the development of curriculum which is oriented on work field/work world and science which is oriented on science integration- interconnection. The development of curriculum that has important position in shaping graduates besides a a professional lecturer. As proposed by Brady (1992), that the development of curriculum should be adapted with the context, process, management, translation and evaluation. 


\section{Literature Review}

\subsection{Relevant Research}

There are some results research that addresses about development curriculum perspective maqashid, including are: First, research by Suwadi about Development Curriculum Education Religion Referring KKNI-SNPT Parad Integration-Interconnection in Program Studies FITK UIN Sunan Kalidjaga. This Research discussing about developing curriculum referring on KKNI-SNPT and integration to interconnection and discussing more about the process of drafting curriculum, but not yet analyzed from perspective maqashid, namely is curriculum developed has meet demands development the desired curriculum by university (whether corresponding with vision, mission, and the goal).

Second, research by Rosidin entitled "Internationalization Education High-Islam Through Realization The Global Goals-Based Maqashid Sharia". This research concluded that the era of globalization be marked shift concept citizenship. From country citizens to be world citizens (global citizenship). The implications is the importance of Islamic education reform based on global standardization. From the country citizens to be world citizens (global citizenship). The implications is the importance of Islamic education reform based on global standardization yet Islamic. The concrete form is the internationalization of Islamic education through the realization of global goals based maqashid sharia. The education model that held is the education that makes maqashid sharia as core curriculum (education model Comprehensive), namely open for all party for earn as well give education (emancipatory), ready compete in global competition (competitive), civilize attitude supple and open to fellow (inclusive), would cooperate with whole world citizens (collaborative) and able to present an actual change for community (transformative).

Both researchers are tightly relate with curriculum development based maqashid, but the first research has not comprehensive talking about the problem of curriculum development because it has not talking about the suitable curriculum with character values the 21 st century needed and important for developed. While the second research has discuss values that are relevant the 21st century, however still on concept stages. While this research tries to elaborate the relevant various value the 21 st century also the planning time in implementation.

\subsection{Theoretical Framework}

In implementation a curriculum, course only no regardless from various shortage. By because it is required existence development or changes in the process of implementation. Development curriculum must could reflect changes in community and education on common. Therefore mostly related with development curriculum pointed on way apply change most effective. Something development curriculum will change community to direction particular, but on basically change curriculum reflect change community.

There is some concept in preparation framework the theory behind research this namely:

\subsubsection{The nature of education curriculum}

Challenge by challenge is faced by learners and education world. The dymanic of environment moves faster than previous period. Even, every time it is found better technological innovation. This situation provides opportunity for each life aspect to follow this rhythm or be left by it. Thus, the educational actors should try to continuously prepare their learners in adapting the dynamic. The challenge faced is that the education should improve the sensitivity in planning and applying the innovation. Therefore, education does not only become routines which lost of meaning. On the other hand, it becomes the dynamist for the life. The tendency of third education wave in international scale indicates a complex condition. Equational institutions do not only function as an educator but also ensure the shaped graduates intelligence.
Naturally, the development of curriculum is the development of curriculum components which shape the curriculum system itself, which are components of objective, material, method, learners, educators, media, learning source etc. Many parties participate in the curriculum development, such as (1) education experts, (2) administrators, (3) teachers; (4) parents; and (5) students. In this case, the author tends to define the curriculum by reviewing the developing words origin. Thus, it is understood that what is intended by curriculum development is change of what exist towards the satisfaction basically has similar principle with rearrangement of curriculum.

Simply, curriculum development theory can be grouped into theory, such as: (1) Theory which emphasizes on the curriculum content; (2) theory which focusses on educations ystem; (3) theory which emphasizes on the curriculum organization. According to Muhaimin, in the development of Islamic education curriculum, at least there are four approaches that can be utilized, such as humanistic, subject academic, social reconstruction, and technological approach. First, humanistic approach departs from humanization idea. Second, academic subject approach. It means that in designing the curriculum or education program is based on certain systemization which is different to systemization with another science. Third, social reconstruction approach; desigining curriculum or program of skilled education departs from problems faced by the society which furthermore play the role of science, technology, and work cooperatively and collaboratively, thus it is found the resolution towards better society shaping. Fourth, technological approach; it designs educational curriculum or program which departs from the competence analysis required to implement certain tasks.

Neil classifies the curriculum development theory: (1) curriculum which is based on philosophy, religion, and art; (2) curriculum which bases on rational approach and field data. According to Pinar, the theory of curriculum can be classified into traditionalist, conceptualist, empiric, and reconceptualist. According to Saylor and Alexander, in the beginning, the development of curriculum uses old concept, in which the curriculum is seen as a content of lessons or primary material offered to learners in completing a learning program in certain education unit. However, following the education autonomy which is parallel with certain demand, the development of science and technology and competitiveness demand in human life, curriculum is not only seen as a set of lesson that should be leant by learners, but has wider meaning in assisting the development of learners' potential through potential learning experience to reach vision, mission, objective and result desired by a set education, which is implemented inside or outside the school environment.

According to al-Qabisi, in the Islamic education curriculum is divided into two: First, ijbari curriculum, curriculum (lesson) is compulsory for each learner. The curriculum content is on the content of al-Qur'an verse, such as shalat and prayer. The mastery of nahwu science and Arabian language is an absolute requirement to firm al-Qur'am readomh. The curriculum on language and written reading al-Qur'an is given on basic level, which is kuttab. The opinion of al-Qabisi on the importance of writting and reading lesson and understanding of al'Qur'an concerning shalat reflects the tendency as a jurist.

Muhammad Athiyah al-Abrasyi perceives that curriculum should compare some following principles: First, there should be lesson aimed to educate spirital aspect. Second, lesson should ecist concerning the instruction and demand to indergo pure and perfect life, such as moral, hadits, jurisprudence etc. Third, lesson learnt by Islamic people because the lesson is scientific and ideologic, which is by major education scientists are called as learning the science itself. In other words, the science should be usable, and fifth, the lesson should be useful to study other science which is instrument science, such as language and all branches.

In the development of curriculum cannot be separated from policy trusted by education believed by the eduacation institution itself. The approach of curriculum development has developed into five modes, which are Tyler, Taba, Technical-Scienttific, non technical 
non scientific and post modern model. The five curriculum model can be explained as follow: First, Tyler model, curriculum development model of Tyler version can be seen in the following table:

Table 1: Curriculum Development Model

\begin{tabular}{|c|c|}
\hline Objective & $\begin{array}{l}\text { What educational purposes should to } \\
\text { school seek to attain }\end{array}$ \\
\hline \multirow[t]{3}{*}{$\begin{array}{l}\text { Selecting } \\
\text { Organizing } \\
\text { Evaluation }\end{array}$} & $\begin{array}{l}\text { experience What educational experiences can be } \\
\text { experience provided that are likely to attain these } \\
\text { purpose }\end{array}$ \\
\hline & $\begin{array}{l}\text { How these educational experiences be } \\
\text { effectively organized? }\end{array}$ \\
\hline & $\begin{array}{l}\text { How can we determine whether these } \\
\text { purpose are being attained? }\end{array}$ \\
\hline
\end{tabular}

Second, Taba model suggests that indicative approach for curriculum approach is started from special to general matters. He proposed some steps to implement curriculum change, such as : Diagnosis of needs, Selection of content, which is content selection. The curriculum content selection with an objective is further steps. Organization content organizes the content. Through selection, the content of curriculum has been determined. The selection of learning experiences are to select a learning experience. Then the teacher determines packs the learning experience that have been determined in the activity packages, students participate so that they have responsibility in carrying out learning activity. Determination of what evaluate and of the way and mean of doing, is to determine evaluation instrument and procedure that should be done by students. Checking for balance and requance.is to test the balance of curriculum content

Third, technical-scientific model. This model is oriented on objectivity, universality, effectiveness, and efficiency. The development of curriculum convers planning, learning environment structure, organizing human resource, materials and instruments, having objectivity and universality degree and high logic. Is able to explain the reality symbolically, believing on efficiency and effectiveness of system and the world is seen as machine that can be drawn, read and observed.

Fourth, non-technical and non scientific model. The development of curriculum is oriented on learners. The development includes orientation towards subjective, personal, beauty, reasoning and transaction, orientation towards learners through active ways in teaching learning activity, curriculum is developed than planned, the world is considered as living thing.

Fifth, post-modern model. This model is oriented on learners to solve their uncertainty. Curriculum is dynamic. It is based on different personal, social and intellectual view. Post-modern intellectual view is based on truth which is appropriate with more pragmatically situation.

Paragraph text/ Tables Figures etc.

\subsubsection{The Design of Education Curriculum Development}

Basically, theoretical curriculum design can be said as similar between Islamic and general education curriculum. What makes it different is the objective that will be achieved by each institution. In the national curriculum (Government Regulation No.19 Year 2005 on Education National Standard), all study programs have been formalized and ready to be implemented by educators or teachers. The curriculum is formal and known as ideal curriculum, which is curriculum in form of aspiration. Curriculum in form of orientation should be developed into the implementation or known as actual curriculum, which is executed by learners in the process of teaching learning. In designing a curriculum (in order to develop the curriculum) very depends on organizational principle, which is in form of presentation or implementation of lesson material (curriculum organization). Therefore, curriculum development design in the Islamic education is directed to how it is designed as Islamic perspective curriculum principles.

As stated by Muhaimin which is quoted by Mujamil, that Madrasah Curriculum should be developed integratively by making teaching and values of religion as the guideline and source of consultation for the development of various public lessons which operation can be developed by implicating Islamic teaching and values into Natural, Social Science etc, so that dichotomic impression does not occur. Then, the learning model can be implemented through team teaching, which is teacher Natural, Social Science etc lesson work cooperatively with PAI teacher in designing learning design concretely and in detail to be implemented in the learning activity. Based on what becomes the focus of teaching, a curriculum design which is called as Subject Centered Design is known, which is a curriculum design that centers on teaching material. Subject centered design is a form of the oldest design and used until present. The curriculum is centered on content and material taught. The curriculum is designed on some lessons and taught separately (separated subjecti curriculum). The curriculum design emphasizes on the knowledge mastery, content, values and past cultural heritage and effort to be heredited to the next generation, so this design is also called

"Subject Academic Curriculum".

As the statement of Tyler and Alexander quoted by Soetopo and Soemarto, this curriculum type is utilized together with school subject and since the past decades until present, many educational institutions use it. This curriculum consists of some lessons which is aimed that learners master the material of each lesson that has been determined by logically, systematically and deeply such as Imla', Nahwu, Sharaf Khat, Muhadastsat, Quran dan Balaghah. There are three subject centered designs, which are:

\subsubsection{The Subject Design}

The Subject Curriculum is the purest design form of subject centered design. This lesson provides separately in form of lesson spies. This design model have existed since the past. Greek people then Roman people developed Trivium and Quadrivium. Trivium includes grammar, logic and rhetoric, while Quadrivium included mathematics, geometric, astronomy and music. At that time, education was not directed to earn money, but shape personal and social status shaping (Liberal Art). Education is only directed to noble children who did not have to work to earn money.

In the 19 Century, education was not directed to liberal art but more practical education, or concerning livelihood (vocational education). At that time, lessons such as physics, chemistry, biology, theoretical language and practical lessons such as agriculture, economics, bookkeeping, family welfare, skill etc have also been developed. The learning content is taken from knowledge and values that have been found by previous experts. Students were demanded to master all given knowledges, whether they like it or not, whether they need it or not. Since the lessons were given separately, they also master it in the same way. It is not often they master the material on memorizing stage, even verbally.

\subsubsection{The Disciplines Design}

This form is the development of subject design. Both designs still emphasize on the curriculum material content. Even though it is opposite to similar things, however, they have difference. On the subject design, there has not been firm criteria on what is called by a subject (science). There has not been difference between mathematics, psychology, and technique or driving method. All is called subject. On the discipline design, the criteria has been firm. What differs is whether a knowledge is science or subject and not the body of science. The body of science determines whether the lesson is discipline or not. In order to confirm it, they use the term of discipline.

The content of curriculum given at school is science disciplines. According to this view, school is micro cosmos of intellectual world, the first stone is the content of curriculum. The curriculum developer of this field holds on science disciplines such as physics, biology, psychology, sociology, etc. Another difference is in the level of discipline design mastery, it is not similar to subject design which emphasizes on facts and information mastery but on understanding. Learners are encouraged to understand logic or basic structure of a discipline, concepts, idea and important prin- 
ciples are also encouraged to understand modes of inquiry and discovery. Thus, they will understand a problem and are able to see the relationship as a new phenomenon.

The learning process does not use expository approach which cause they are more passive, but use inquiry and discovery. Discipline design has integrated Dewey's progressivism elements. This form has some strengths compared to subject design. First, this curriculum only has systematic and effective organization but also maintain human's knowledge intellectual integrity. Second, learners do not only master a set of facts, memorizing result principles but mastering the concept, relationship and intellectual process which develop on students.

Although it has indicates some form strengths, this design still has some weaknesses. First, it has not given integrated knowledge. Second, it has not able to integrate between school and society or life. Third, it has not departed from interest and near or experience of learners. Fourth, curriculum arrangement has not been efficient for learning actitivity or its use. Fifth, although it has been wider than subject design, but academically and intellectually is narrow.

\subsubsection{The Broad Fields Design}

Both subject design and discipline design indicate separation among lessons. One of efforts to remove the separation is by developing it. The broad field design. In this model, they unite some lessons which close to each other or are combined into a study field. The objective of broad field curriculum development is to prepare students nowadays live in specialist information world, with total understanding. The form of curriculum is used at Junior High School, senior high school, and university or college. There are two strengths of curriculum use. First, basically the material is separated. Even though the mixing of course, it still enables the design based on certain objectives and cultural heritage systematically and in order. Second, since integrating some courses, it enables learners to see relationship in some more contextual things.

Beside the strength, there are some curriculum mode weaknesses. First, teachers'/lecturers' competence. For primary school level, teachers are able able to master broad field, however, for higher level, such as universities, students are able to think contextually and actually. Second, since the learnt field is wide, it can be more comprehensive to cover learnt science discipline. The learning strategies which is appropriate with this design are problem based learning and project based learning.

\subsubsection{Approach of Education Curriculum Development}

Curriculum development is influenced by various factors. Those factors are: social and effort of society's group and parents, institutions, professional institution, university, national education institution, school development program, etc. Kimball Wiles and Woodrow Sugg that the effects of Social Conditions are (a) international condition. A survey conducted by NEA research division on more than 4000 school systems indicated that mobilization and defensive efforts have created a number of changes and adaptation on school and university curriculum, which are to improve the acceleration process of curriculum revision, the emphasis is on vocational program, more on physical education program. It emphasizes on vocational program, more on physical education, the emphasis is on social lesson/review, and development on first aids and security training, science, offering advertisement and home economy; (b) national problems, such as the high number of accident, monetary policy, conflict among social group.

Nana Syaodih Sukmadinata mentioned that curriculum development or in her terms. It is mentioned various kinds of curriculum concept, such as academic subject curriculum, humanistic curriculum, technological curriculum and social reconstruction curriculum.

\subsubsection{Academic Subject Approach}

Academic subject curriculum is sourced from classical education (perenialism and essentialism) which are oriented on the past. All knowledge and values have been invented by the past thinkers. Education function maintains and hired it the past cultural results. This curriculum more emphasizes on the education content. Learning is to try to master as much science as possible. Success people in learning are they who master all or most of education content which is given or prepared by the teacher.

The education content is taken from science discipline. All discipline fields of scientists have developed the science systematically, solid, and logically. The curriculum developers do not need to design and develop their own material. They have just to select the materials that have been developed by scientists of science discipline and organize it systematically as the objective of education and students' development stage that will learn it.

The objective of academic subject curriculum is to provide solid knowledge and train students to use the ideas and process of "research." Thus, it is expected that they have concepts or methods that will be developed in the wider society. School should give opportunity for students to realize their ability to familiarize cultural heritage and if it is possible, enrich it.

The most methods utilized in the academic subject curriculum is expository and inquiry method. Ideas given by the teacher is elaborated (implemented) by students until they master it. The main concept is arranged systematically with clear illustration, furthermore it is reviewed. Then it is formulated and found the solution. The approach of social reconstruction curriculum development pays attention to curriculum relationship with society, politic and economic development. Many of this group principles are consistent with the highest aspiration, for example human rights case of minority group, belief in general society intellectual, and the ability to determine their own destiny as the direction desired by them. Thus, this approach is as the social condition in each society both in Thailand or Indonesia

Through the process, students will find that thinking and observing ability are used in the science of natural, logic in mathematics, form and feeling utilized inart and coherence in the history. They teach standard books to enrich their knowledge and understand the past and present culture.

On the evaluation activity, curriculum of academic subject uses various evaluation types adapted with the objective and characteristics of lesson. In humanity study, it more utilizes essay tests than the objective. The study program requires answers which reflect logic, coherence and integration comprehensively. Art study program is expressive, so it requires subjective and honest assessment, besides beauty and taste standard. It is different with mathematic, the highest value is given to students when they master axioma base and good calculation method. In the natural science, the highest appreciation is not given to correct answer but the thinking process utilized by students.

A big problem faced by developers of academic subject is how to select lesson of many existing science disciplines. If we want to master deeper, the number of science difficult should be less. If they only teach less science discipline, the students' mastery will be limited, they will find difficulty in the wide society life. If the science disciplines are many, the mastery will be shallow. There are some suggestions to solve the problem, such as: (a) Trying comprehensive mastery by emphasizing on how to test truth and get the knowledge; (b) Prioritizing social utility, select and determine aspects of science discipline which is required in the social life; (c) Emphasizing basic knowledge, which is knowledge becomes the basic of other science mastery.

The development of academic subject curriculum more emphasizes on logic and systematic material organizing than synchronizing the order of material on children's thinking ability. Generally, they pay attention to students who study and more emphasize on content arrangement, which is what is taught. The learning process which is undergone by students is as similar to the concept mastery, principles, and generalization. The experts of academic subject curriculum also see the material that will be taught is universal, they ignore the students'characteristic and local society needs. In order to handle the weaknesses, some perfection is done in further development. First, to balance the emphasis of thinking 
process, they push the use of institution and riddles. The efforts to adjust the lesson with individual difference and local needs. Third, facility use and sources in the society.

\subsubsection{Humanistic Approach}

Humanistic curriculum is developed by humanistic education experts. This curriculum is based on personalized education that is John Dewey (Progressive Education) and J.J Rosseau (Romantic Education). This ideology gives main place for students. They depart from the assumption that children or students are the first and main in the education. They are the subjects that become the center of education activity. They believe that students have potentials or ability and power to develop. Humanist educators also hold on the concept of Gestalt that individual or child is a unity. Education is directed to guide intact human, not only seen from physical and intellectual but also social and affective (emotion, attitude, feeling, interest, etc).

Their view develops as the reaction towards an education which more emphasizes on intellectual aspect and the main role is held by the teacher. Humanistic education emphasizes on the role of students. Education is an effort to create permissive, relax and intimate situation.

Their education more emphasizes on how to teach students (encourage them) and how to feel and behave towards something.

The objective of teaching is to broaden self-awarness and reduce estrangement and alienation from the environment. There are some ideologies including in the humanistic education, such as education: confluent, radical criticism, and modern mysticism.

Humanistic curriculum has some characteristics, concerning the objective, method, content organization and evaluation. According to curriculum humanist experts, it functions to provide meaningful experience to help smoothing students' personal development. For them, the objective of education is dynamical personal development process which is directed to growth, integrity, and autonomy of personality, healthy attitude towards themselves, other people and learning. All is a part of self-actualizing person.

Humanistic curriculum demands good relationship between teachers and students. Besides, teachers can create warm relationship, can become sources, and give interesting material, and able to create which smooths the learning process, teacher provide support for students on trust feeling. Teaching role is not only done by teacher but also students. Teachers do not force something disliked by students.

In the humanistic curriculum evaluation is different with the usual. The model emphasizes on the process than result. If it is common curriculum, especially academic subject, has achievement criteria. Thus, humanistic curriculum does not have criteria. The target is children's development becomes more open human, and stand by itself. Their activity should be useful for students. Better learning activity gives experience that will help students to broaden their selves awareness and other people and can develop potentials possessed by them. Subjective assessment is done by teacher towards the students.

\subsubsection{Technological Approach}

In line with the development of science of technology in education field, the technology education also develops. This principle has similarity with classical education, which is to emphasize on the curriculum content, but it is directed not on maintenance and preservation of the science but the mastery of competence. A bigger competence is narrower, more special and finally behaviors that can be observed and measured.

The implementation of technology in education field, especially curriculum is in form of two types, which are software and hardware. The implementation of hardware in the education is known as tools technology, while the implementation of software technology is also called system technology.

Education technology in instrument technological meaning, more emphasizes on technological instrument use to support efficiency and effectiveness of education. The curriculum contains of use plans of various instruments and media, also teaching models that involve the instrument use. The teaching model examples are: video/film-assistance, programmed, machinery, module, computer-assistance teaching.

In system technology meaning, education technology emphasizes on the teaching program or lesson plan organization by using system approach. This teaching program can be merely a system program which can be supported by instrument and media, or combined with teaching instrument or media.

Curriculum which is developed from education technological concept has some special characteristics, which are:

(a) Objective: The objective is directed to competence mastery, formulated in form of behavior. General objectives are competence which are detailed into special objectives, or called as instructional objective; (b) Method. Method is a learning activity which is often seen as a process of reacting towards stimulus given and if there is response, it is expected that it will be strengthened; (c) Material organization. Material organization or content of curriculum is taken from science discipline but is has been combined to support the mastery of competence; and (d) Evaluation. Evaluation activity is performed anytime, in the last session of learning, unit or semester.

Technological teaching program very emphasizes on efficiency and effectiveness. The program is developed through some trial activity towards samples of appropriate population is revised some times until the expected standard is achieved. With the teaching model, the students' mastery level in conventional standard is far higher than other models. Moreover, if the programs are more structured as the programmed teaching, module teaching or teaching with video and computer assistance, completed by feedback systems and organized guidance can accelerate and improve the students' mastery.

This model is limited to teach complex teaching material or which needs high level mastery (analysis, synthesis, evaluation), also affective teaching materials. Some trials indicate that student's' competence to transfer the learning result is low. Technological teaching is difficult to serve learning students' talents with special methods. Their teaching method tend to be uniform, if their attitude is positive, students will be successful, if not, their mastery level is relative low. Boredom problem also affects the learning process.

\subsubsection{Social Reconstruction Approach}

Social reconstruction curriculum is different with other curriculum models. This curriculum centers the problem on problems faced by the society. This curriculum is sourced from interactional education line. According to them, education is not their own effort, but collective activity, interaction, cooperation (teacher-students, student-student, student-environment student-learning source etc). Through this interaction and cooperation, students try to solve the problems experienced by them in the society towards better society shaping.

Social reconstruction curriculum development approach, it pays attention to curriculum relationship with society, politic, and economic development. Many group principles are consistent with the highest aspiration, for example human rights of minority group, belief and intelligence of public society and ability to determine their own destiny as the direction which is desired by them, thus, this approach is appropriate with social condition in each society both Thailand and Indonesia.

\section{Methodology/Materials}

\subsection{Type of research}

This research use qualitative paradigm that try to explain the phenomenon naturally. The knowledge approach that used are anthropology and sociology of education. 


\subsection{Technique of Data Collection}

Collecting data use depth-interview, observation, and watching closely to the document. Interview technique is use to reveal the historically data about the establishment of the school and the local wisdom values that dominat. The informants are students, teachers, head master, parents, and the society.

\subsection{Technique of Data Analysis}

The data was analyzed with interactive analysis developed by Miles Huberman which consist 4 steps: (1) data collection, (2) data reduction, (3) data display, and(4) taking conclusion. Paragraph text/ Tables Figures etc.

\section{Results and Findings}

Paragraph text/ Tables Figures etc.

a. The Development of Islamic Religion Education Curriculum which is Based on Maqashid (Objective)

The development of curriculum implemented on Study Program of Islamic Religion Education (IRE) always finds the actal shape and format, however, in relative long time since 2012, which is since the issue of curriculum-based Indonesian National Qualification Design (INQD). Internal party who is involved such as academia civet of Islamic Religion Education Study Program and external party has been given a suggestion by stakeholders, graduates users, graduates and experts in their field, both in abroad such as UGM, Association Forum of IRE Indonesia, and Review of Prof Team and Marry Galegard from Australia. The last is the approval result of Tarbiyah Science and Teachers Training Faculty of UIN SUnan Kalijaga Yogyakarta (D/PAI/2015).

The implementation of INQD of college field is marked with Presidential Decree number 8 year 2012, Indonesian Presidential Decree Number year 2012 and Regulation of Educational and Cultural Mlinstry RI number 73 year 2013 require universities, including UIN SUnan Kalijaga to redesign separated curriculum at the latest in the Academic Year 2016/2017. There are some reasons of redesigning UIN Sunan Kalijaga curriculum. First, since the standardization of education quality both in the national or international level. Second, values proposedby globalization experiences development from time to time, such as humanistic and multicultural value, especially in interacting globally. Third, prepare UIN Sunan Kalijaga towards world class university stage. The following will be discussed about the preparation in designing curriculum, respectively.

\subsection{Curriculum Design Preparation}

Learning Outcome (LO) design is a systematic effort in renewing curriculum applied in IRE Study Program. More specifically concerning the curriculum sophistication, the following. (Picture 1. Chronology of Competence-Based Curriculum-Indonesian National Quality Design of Islamic Religion Education Study Program.

The design of Learning Objectives (LO) are focused on the requirement as an effort to fulfill the graduates' profule, society's requirement to get prior, competent and competitive graduates. Besides the learning achievement formulation, it covers four professional teachers' competence (pedagogia, social, personality and professional competence) and leadership competence for teachers in the Religion Ministry. The formulation of learning outcome has fullfilled the competence indicators of Islamic Religius Lesson teacher's competence, therefore, the LO formulation I very important and becomes the heart of study program. The LEO becomes the reference to organize curriculum revision. In 2013 , Competence-Based Curriculum-Indonesian National Quality Design has been prevailed comprehensively to follow the regulation. The Curriculum of IRE Study Program year 2013 refer to Competence-Based Currculum (CBC) which refer to Indonesian Qualification Framework (IQF).
In the curriculum development context, basically the curriculum review can be performed each year, however the evaluation can be performed each 4 years. The four year agenda is the curriculum sophistication tradition as the internal and external development. The curriculum evaluation activity has been designed since 2010 by presenting education experts and practitioners to discuss teaching schools seminar. The result of building teaching schools becomes the reference to perform curriculum workshop simultaneously on curriculum redesign at Tarbiyah Faculty (at the time). The workshop result was reviewed by Australia Team in 2011. One year later (2012) it was done external experts' review which presents curriculum team of DIKTI Diknas and resource from UGM and State University of Yogyakarta. The next step is Focus Group Discussion performed by Islamic Religion Education teachers, graduates, students and school/madrasah principals. Internally, internal expert review has been performed internally, they are lectures of Islamic Religion Education Study Program and the result will be discussed in the senate of faculty and university senate. After the perfection, in 2013, Launching New Curriculum of Academic Year 2013/2014 was performed.

On the set, it is gradually breakdown in the syllabus activity, a set of study or semester course activity program

planning. The activity has not run and controlled the academic if the description of the course is not arranged. In 2015/2016, the review has followed the development demand both internally or externally, science discipline role, education objective dynamic, material, method, and education evaluation. Therefore, in the academic year 2016/2017 applies and prevails curriculum which refer to Indonesian National Qualification Competence and NSUniversity with integration- interconnection approach as the vision of UIN Sunan Kalijaga (W/IRE/2016). Furthermore, the socialization of LO IRE Study Program through vernal or written form. Written forms are book publishing of Course Description, Academic Guideline of Tarbiyah and Teacher Science faculty, banner, leaflet, calendar and website. Verbal socialization is done through various forums such as coordination meeting, workshop, general course and seminar.

\subsection{The Profile of Islamic Religion Education Study Program}

Islamic Religion Education Study Program has been established since 29 September 1962 based on the determination of Religious Minister No.43 Year 1960 on State Islamic Religion Institute Establishment and Religion Ministerial Decision number 2 Year 1962 on the Opening of Tarbiyah and Arab Faculty in Yogyakarta, at that time it was called as Religion Education Study Program, then it has been renamed into Islamic Religion Education Study Program. As the Decision of Directorate General of Islamic Education changed Dj.I/39/2010 on Licence Extension of Study Program on State Islamic University Sunan Kalijaga Yogykarata in 2010 has been changed into Islamic Religion Study Program. The three profiles of Islamic Religion Study Program are as Islamic Religion Teacher. Islamic Religion Education councelor, learning outcome on each profile as follows : first, theacehrs of Islamic Religion Education at school/madrasah that have good character and integrity, knowledge and sophisticated in Islamic Religion education field, and able to apply education theories and learning, also to be responsible towards the implementation of task which is based on universal values which prioritizes balance, justice with Islamic Ethics, science, expertise and profession. Second, being a councelor od Islamic Religion Education at competent schools/madrasah, master children's psychology and are able to do learning course and Islamic Religion practice of school as children and responsible towards the implementation of tasks which are based on universal values which prioritizes balance, justice, with Islamic Ethics, expertise and profession.

Referring on the profile and LO which are determined at IRE Study Program, the curriculum is designed with some

considerations, such as the requirement and objectives of stakeholder, labour market and appropriateness with vision and mission of the university or faculty (maqashid). The curriculum which is prevailed by IRE Study Program at present is university curricu- 
lum which refers to Indonesian Qualification Framework (IQF) with integration-interconnection science approach. In this curriculum, the study program course is designed based on Expected Learning Outcome (ELO) which is harmonious with graduates profiles that have been determined in the Program Learning Outcome (PLO) and elaborated in Course Learning Outcome (CLO) and Lesson Learning Outcome ( $L L O$ ). The organization of courses as the ELO as done by following the guideline of curriculum design based on INSQ. ELO is organized in a matrix so that it is arranged as the determined ELO. In order to assure that curriculum structure is arranged as the ELO. IRE Study Program performs curriculum structure review which involves lecturers, stakeholders, students and alumnus. Furthermore, the draft is reviewed on te faculty and Quality Insurance Institution (QII) level to assure the course content and the review material as the ELO. Curriculum review is done through the following stages, which are limited review (involve Islamic Religion Education Lecturer), broad review (involve stakeholders and education experts), and indepth review (involves faculty senate and Public Service Institution). Therefore, the development of curriculum is performed systematically and planned.

Student assessment as performed by IRE Study Program is directed to see the achievability of LO and feedback for

the study program and lecturers. The ssessment system which is performed includes assessment during new students selection. The assessment is carried out during the course period and in graduation determination. Each assessment which is done always pays attention to the validity, reliability, and objectiveness of assessment. The type of assessment is also impelemted not always by the lecturer to the students, but by students to the lecturer, among the students, and self- assessment. Students can communicate the value outcome towards the Study Program, including the accommodation of student appeal on the obtained value.

Besides the learning model and assessment system, the implementation of course at IRE Study Program is also supported by the availability of human resource, bot academic staff (lecturer) or supporting staff (administration, librarian, laboratory assistant, and TI staff). The fulfillment of Human Resource need is fullfilled through recruitment system by considering academic qualification and skill/competence which is appropriate.

\subsection{Islamic Religion Education Curriculum which is based on Maqashid; Refer to IQF, NSU, and Integration- Interconnec- tion}

The curriculum of IRE Study Program of Tarbiyah and Teachers Science Faculty is said as based on Maqashid because it is relevan with the vision of Sunan Kalijaga, which is integration and interconnection of science and refer to IQF and NSU which at present becomes the government's policy. Through curriculum which is based on Maqashid, UIN Sunan Kalijaga has the opportunity to implement their vision and mission in developing interdisciplinary and multidisciplinary review with integrative and interconnective approach for taking a part of dichotomy between science and religion, religious science and general science, sacral and proven. In formulating the curriculum that integrates and interconnects Islamic and general science, the study program uses integrationinterconnection concept. It appears start from the achievement of learning to learning method. In order to beat out the integrationinterconnection concept of science which is developed by UIN SUnan Kalijaga, further explanation on it can betraced from official documents of UIN Sunan Kalijaga, for example: Foundation Book of Science Integration-Interconnection, IntegrationInterconnection Aspect, etc.

A curriculum should also have relevance aspect. Based on the approach in curriculum development as mentioned earlier, relevance aspect is important. The curriculum of IRE is developed based on the academic approach and social reconstruction, because it is based on integration and interconnection of science and IQF and NSU that becomes government policy to give contribution towards social problems. The relevance includes two things. First, the relevance between curriculum with demand, needs, con- dition and society's development. Both relevances among curriculum components, which is relevant with the objective, process as the content and objective. Also, the evaluation as the proves, con-

tent, and objective of curriculum Although the component term is proposed differently, however it has similar points,

such as (1) Objectives; (2) Content and curriculum structure; (3) strategy (Teaching Learning Process), and (4) Evaluation.

\section{Conclusion}

Based on the research discussion result on the development of curriculum at university, it can be concluded that

1 Curriculum of Islamic Religion Education, Tarbiyan and Teacher Science Faculty, State Islamic University (SIU) Sunan Kalijaga is based on Maqashid because it is relevant with the vision, mission and objectives of Sunan Kalijaga, which is integration and interconnection of science and refer to IQF and NSU which at present has become the policy of government. Through the development of curriculum which is based on Maqashid, SIU Sunan Kalijaga has an opportunity to implement their vision and mission in developing interdisciplinary and multidisciplinary reviews with integrative and interconnective approach.

2 According the approach in developing curriculum as mentioned before, the relevance aspect is important and curriculum Islamic Religion Curriculum is developed based on academic approach and social reconstruction, because it is based on the integration and interconnection of science and IQF and NSU that become the government's contribution $t$ social problems resolution. The relevance includes two things. First, the relevance between curriculum and demand, requirement, condition and society's development. Both relevances between curriculum components, which are content that relevant with the objective, process is relevant with the content and objective, and evaluation is relevant woth process, content, and objective of curriculum.

3 The curriculum development of Islamic Religion Education Study Program, Tarbiyah and Teacher Science Faculty SIU SUnan Kalijaga Yogyakarta emphasizes on (a) intelligibility of graduates profile and operational description, (b) learning outcome as the indicator of graduates' profile outcome that refers to IQF and NSU;

4 IRE review field as the scope ofcorse nama development scope which is combined with the learning achievement,

(d) semester credit unit weight is obtained from the multiplication between the depth and spaciousness of review material; second, curriculum development accommodate professional teacher's competence with four competences; pedagogic, personality, social, professional, and plus leadership.

\section{Acknowledgement}

This research work is supported by the Project (71372111) supported by NSFC.

\section{References}

[1] Miller S, Steinberg RH. Transport of taurine, L-methionine and 3o-methyl-D-glucose across frog retinal pigment epithelium. Experimental eye research. 1976;23(2):177-89. 